\title{
EFEKTIVITAS KAPORIT PADA PROSES KLORINASI TERHADAP PENURUNAN BAKTERI Coliform DARI LIMBAH CAIR RUMAH SAKIT X SAMARINDA (The Effectiveness of Calcium Hypochlorite to Chlorination Process in Decreasing the Amount of Coliform Bacteria in the Wastewater of X Hospital, Samarinda)
}

\author{
Muhammad Busyairi*, Yodi Prapeta Dewi dan Devita Irianti Widodo \\ Program Studi Teknik Lingkungan, Fakultas Teknik Universitas Mulawarman, \\ Kampus Gunung Kelua, Jalan Sambaliung no. 9 Samarinda 75119.
}

*Penulis korespondensi. Tel: 0541-736834. Email: busyairi22@ gmail.com.

\begin{abstract}
Abstrak
Kaporit pada limbah cair rumah sakit digunakan sebagai desinfektan, tetapi, penggunaan kaporit dengan dosis yang tidak tepat akan menyebabkan pembentukan senyawa Trihalomethane (THMs) yang beracun dan bersifat karsinogenik. Pada limbah cair rumah sakit X Samarinda, diperoleh nilai MPN Coliform sebesar >160.000 MPN / $100 \mathrm{~mL}$ dengan residu klor sebesar $0 \mathrm{ppm}$. Penelitian ini bertujuan untuk menentukan dosis optimum dari penggunaan kaporit menggunakan titik Breakpoint Chlorination (BPC) dan pengaruhnya terhadap penurunan Coliform. Analisis dilakukan dengan titrasi iodometri dan menghitung jumlah bakteri Coliform memakai metode Most Probable Number (MPN). Penentuan dosis kaporit berdasarkan dosis optimum pada titik BPC dimaksudkan agar dapat menjaga residu klor dari penambahan dosis yang semakin meningkat. Hasil penelitian mempengarui rerata kadar bahan organik pada sampel limbah cair sebesar 137,26 ppm, sehingga dosis kaporit yang dibubuhkan dimulai dari 130-165 ppm. Titik BPC terjadi pada pembubuhan klor aktif 160 ppm untuk kedua waktu kontak yaitu 30 dan 40 menit. Pada titik BPC, waktu kontak 30 menit diperoleh rerata persentase penurunan nilai Coliform yaitu 98,21\% sebesar $2.899 \mathrm{MPN} / 100 \mathrm{~mL}$ dengan residu klor sebesar 88 ppm. Pada waktu kontak 40 menit diperoleh persentase penurunan bakteri Coliform hingga $98,83 \%$, yaitu dari $>160.000 / 100 \mathrm{~mL}$ menjadi $1.866 / 100 \mathrm{~mL}$ dengan residu klor $97,5 \mathrm{ppm}$.
\end{abstract}

Kata kunci: breakpoint chlorination, coliform, kaporit, limbah cair, rumah sakit.

\begin{abstract}
Calcium hypochlorite of hospital wastewater serves as disinfectant, however, inappropriate dose of it will lead to the formation of Trihalomethane (THMs) which is toxic and carcinogenic. The value of MPN Coliform of wastewater in $X$ hospital Samarinda is $>160.000$ MPN / $100 \mathrm{~mL}$ with residual chlorine 0 ppm. This research aims at determining the optimum dose of calcium hypochlorite usage by using Breakpoint Chlorination curve and its effect to Coliform decrease. Further, the analysis is done by employing iodometric titration and the amount of Coliform bacteria is calculated by using Most Probable Number (MPN) method. Calculation of calcium hypochlorite dose is based on the optimum dose at Breakpoint Chlorination (BPC) in order to maintain the residual chlorine from the addition of increasing doses. The research result has an impact on the average of organic substance in wastewater sample, it is about 137,26 ppm, so the dose of calcium hypochlorite needed is between 130-165 ppm. BPC curve occurs at 160 ppm of active chlorine for both contact time 30 and 40 minutes. At the BPC point of 30 minutes contact time obtained a mean percentage reduction of Coliform value is $98.21 \%$ which is 2,899 MPN/100 mL with residual chlorine 88 ppm. Besides, at 40 minutes contact time obtained the percentage reduction of Coliform bacteria up to $98.83 \%$, it is from >160,000/100 mL to 1,866.67/100 mL with residual chlorine 97.5 ppm.
\end{abstract}

Keywords: breakpoint chlorination, coliform, calcium hypochlorite, wastewater, hospital.

\section{PENDAHULUAN}

Salah satu hasil keluaran limbah yang dihasilkan oleh Rumah Sakit X Samarinda adalah limbah cair. Limbah cair apabila tidak dikelola dan ditangani dengan benar maka akan menyebabkan dampak pada perairan dan lingkungan, terlebih jika limbah cair dari rumah sakit bersifat infeksius seperti limbah cair dari ruang operasi maupun laboratorium karena dapat mengandung berbagai macam mikroorganisme baik yang patogen maupun infeksius (Anonim, 1999). Pada limbah cair Rumah Sakit X Samarinda, diperoleh nilai MPN coliform pada bak outlet IPAL sebesar $92.000 \mathrm{MPN} / 100 \mathrm{~mL}$ dan 160.000 MPN/100 mL pada limbah cair yang berada di bak outlet filtrasi. Nilai MPN coliform limbah cair pada outlet IPAL yang tinggi menunjukkan bahwa proses klorinasi belum optimal. 
Nilai Coliform pada hasil keluaran limbah cair pada bak outlet IPAL menunjukkan angka yang tinggi dan telah melewati baku mutu lingkungan untuk kegiatan rumah sakit berdasarkan Perda Kaltim No.2 tahun 2011. Proses klorinasi dilakukan untuk meningkatkan kualitas air secara kimia yang pada akhirnya akan mempengaruhi kualitas bakteriologisnya. Rumah Sakit X Samarinda menggunakan kalsium hipoklorit $\left[\mathrm{Ca}(\mathrm{OCl})_{2}\right]$ atau kaporit pada proses klorinasi yang diterapkannya. Kaporit dipilih sebagai desinfektan dalam pengolahan limbah cair karena menurut Said (2007), klor pada kaporit terutama $\mathrm{HOCl}$ umumnya sangat efektif untuk inaktivasi patogen dan bakteri indikator. Selain itu, menurut Ali (2010), kaporit digunakan sebagai desinfektan karena harganya yang lebih murah, lebih stabil dan lebih melarut dalam air. Menurut Andhika dkk (2013), pemberian Kaporit menghasilkan penurunan bakteri E.coli yakni berkisar 992,56/100 mL menjadi 7,28/100 $\mathrm{mL}$ sampel air. Menurut Rosyidi (2010), penambahan kaporit pada titik Breakpoint 55 ppm pada air limbah Rumah Sakit di kota Sidoarjo dapat menurunkan nilai bakteri Coliform dari $>1,6 \times 10^{5}$ sel/100 mL menjadi $2 \times 10^{2} \mathrm{sel} / 100 \mathrm{~mL}$ pada waktu kontak 15, 30 dan 45 menit.

Penggunaan kaporit dengan dosis yang semakin meningkat akan menghasilkan residu klor yang tinggi pula (Davis, 2001). Penentuan dosis kaporit berdasarkan kadar bahan organik yang terkandung dalam sampel limbah cair memperlihatkan bahwa, semakin tinggi nilai kadar bahan organik, maka semakin besar pula dosis kaporit yang diberikan, untuk itu diperlukan penentuan dosis kaporit berdasarkan dosis optimum pada titik breakpoint chlorination dan waktu kontak optimum dalam proses klorinasi limbah cair Rumah Sakit X Samarinda agar dapat menjaga residu klor dari penambahan dosis yang semakin meningkat. Dengan demikian senyawa organohalogen berupa trihalomethan (THMs) yang bersifat toksik dan mutagenik dapat dikendalikan. Tujuan lain adalah untuk mengetahui waktu kontak optimum dalam proses klorinasi dari 30 dan 40 menit untuk menurunkan nilai coliform dalam limbah cair Rumah Sakit X Samarinda.

\section{METODE PENELITIAN}

\section{Waktu dan Lokasi}

Waktu penelitian dilaksanakan pada bulan September-Desember 2014. Pengambilan sampel air limbah Rumah Sakit X Samarinda dilakukan pada bulan September 2014. Penelitian dimulai pada bulan September-Oktober 2014. Lokasi penelitian ini dilaksanakan di Laboratorium Rekayasa Lingkungan dan Laboratorium Teknologi Kimia, Fakultas Teknik Universitas Mulawarman Samarinda. Lokasi pengambilan sampel untuk penelitian dilakukan di IPAL Rumah Sakit X Samarinda.

\section{Prosedur Penelitian}

Pada penelitian ini, dilakukan perlakuan penambahan kaporit terhadap sampel limbah cair rumah sakit. Sampel ditambah kaporit sesuai dosis hasil penelitian. Terhadap sampel sebelum dan sesudah inkubasi maka dilakukan pengukuran $\mathrm{pH}$ dan suhunya. Selanjutnya dilakukan penentuan jumlah bakteri coliform dilakukan memakai metode (MPN) terhadap sampel limbah akibat perlakuan kaporit.

Terhadap sampel sebelum dan sesudah inkubasi makan dilakukan pengukuran $\mathrm{pH}$ dan suhu sampel. Untuk menentukan dosis kaporit secara lebih teliti maka sebelumnya dilakukan pengujian kadar bahan organik. Prosedur selengkapnya disajikan pada bagian analisis. Pada kaporit yang digunakan juga dilakukan pengujian nilai klor aktif dalam larutan serta residu klor aktif setelah perlakuan. Efektivitas perlakuan kaporit terhadap limbah cair rumah sakit dilakukan dengan analisis jumlah bakteri Coliform. Metode yang digunakan adalah metode Most Probable Number (MPN) sesuai prosedur (Anonim, 2008).

\section{Prosedur Analisis \\ Analisis pengujian kadar bahan organik}

Pengujian kadar bahan organik sampel diukur memakai titrasi kalium permanganat (Anonim, 2004) dengan 3 kali ulangan. Sampel sebanyak 10 $\mathrm{mL}$ diencerkan memakai $90 \mathrm{~mL}$ akuades di dalam erlenmeyer $250 \mathrm{~mL}$. Kemudian ditambah 2,5 mL asam sulfat $8 \mathrm{~N}$ dan $10 \mathrm{~mL}$ larutan $\mathrm{KMnO}_{4} 0,01 \mathrm{~N}$ hingga berwarna merah muda. Larutan dididihkan selama 10 menit dan ditambah $10 \mathrm{~mL}$ asam oksalat $0,01 \mathrm{~N}$ hingga menjadi tidak berwarna. Kemudian dititrasi memakai $\mathrm{KMnO}_{4}$ 0,01 N sampai muncul warna merah muda lagi. Kemudian dihitung memakai persamaan (1) berdasarkan volume $\mathrm{KMnO}_{4}$ yang dibutuhkan (Anonim, 2004).

$$
\text { kadar } \mathrm{KMnO}_{4}(p p m)=\frac{(10+\mathrm{a})-(10 \times \mathrm{C}) \times 31,6 \times 1000}{d}
$$

Ket. : a. Volume $\mathrm{KMnO}_{4}$ yang dibutuhkan $(\mathrm{mL})$
b. Normalitas $\mathrm{KMnO}_{4}(\mathrm{~N})$
c. Normalitas asam oksalat $(\mathrm{N})$
d. Volume sampel yang digunakan $(\mathrm{mL})$ 


\section{Penentuan dosis kaporit}

Pengujian nilai klor aktif dalam larutan kaporit

Pengujian nilai klor aktif dalam kaporit dilakukan memakai metode titrasi iodometri. Kaporit sebanyak $1 \mathrm{~g}$ dilarutkan ke dalam $1 \mathrm{~L}$ akuades dan kemudian diambil sebanyak $25 \mathrm{~mL}$ dan dimasukkan ke dalam erlenmeyer $250 \mathrm{~mL}$. Ditambah $1 \mathrm{~g}$ kristal KI dan 2,5 $\mathrm{mL}$ asam asetat glasial, kemudian ditetesi dengan indikator amilum hingga muncul warna biru. Kemudian larutan dititrasi memakai natrium tiosulfat $0,0125 \mathrm{~N}$ hingga tidak berwarna. Nilai klor aktif dihitung berdasarkan jumlah natrium tiosulfat yang dibutuhkan memakai persamaan 2 (Shovitri, 2011). Klor aktif $(\mathrm{ppm})=((A-B) \times N$ titran $\times 35,45) /$ ( $m$ L sampel)

Ket : A = Volume titran $(\mathrm{mL})$

$\mathrm{B}=$ Volume blanko (akuades $0 \mathrm{~mL}$ )

Setelah nilai klor aktif diperoleh, dilakukan penentuan dosis larutan kaporit yang akan dibubuhkan kedalam sampel limbah cair rumah sakit. Berdasarkan nilai bahan organik dan nilai klor aktif tersebut, volume larutan kaporit yang dibubuhkan dalam perlakuan sampel dihitung berdasarkan persamaan 3 .

$\mathrm{N}_{1} \times \mathrm{V}_{1}=\mathrm{N}_{2} \times \mathrm{V}_{2}$

di mana :

$\mathrm{V}_{1}=$ Volume sampel yang digunakan $(150 \mathrm{~mL})$

$\mathrm{N}_{1}=$ Dosis kaporit yang diinginkan berdasarkan kadar bahan organik awal (130, 135, 140, $145,150,155,160$ dan 165 ppm)

$\mathrm{V}_{2}=$ Volume larutan kaporit yang di cari $(\mathrm{x} \mathrm{mL})$ $\mathrm{N}_{2}=$ Nilai klor aktif dalam larutan kaporit (ppm)

Pengujian residu klor aktif setelah perlakuan sampel

Pengujian nilai residu klor aktif dalam kaporit juga memakai metode titrasi iodometri. Sampel limbah cair yang telah dibubuhkan larutan kaporit diambil sebanyak $25 \mathrm{~mL}$ dan dimasukkan ke dalam erlenmeyer $250 \mathrm{~mL}$. Selanjutnya dilakukan penambahan $1 \mathrm{~g}$ kristal $\mathrm{KI}$ dan 2,5 $\mathrm{mL}$ asam asetat glasial, kemudian ditetesi dengan indikator amilum hingga muncul warna biru. Kemudian larutan dititrasi dengan natrium tiosulfat $0,0125 \mathrm{~N}$ hingga tidak berwarna. Nilai klor aktif dihitung berdasarkan jumlah natrium tiosulfat yang dibutuhkan dengan persamaan (Shovitri, 2011) seperti persamaan (4)

Klor aktif $(p p m)=((A-$ B) $x N$ titran $x 35,45) /(m L$ sampel $)(4)$

Ket : A = Volume titran $(\mathrm{mL})$

$\mathrm{B}=$ Volume blanko (akuades $500 \mathrm{~mL}$ )

\section{Uji Most Probable Number (MPN) Coliform}

Pada uji penduga, tabung reaksi yang berisi Lactose Brooth (LB) yang menunjukkan hasil positif, diinkubasi pada tabung berisi media Brilliant Green Lactose Brooth (BGLB) 2\% dan tabung durham untuk uji konfirmasi. Coliform ditentukan memakai inkubasi pada suhu $36^{\circ} \mathrm{C}$ selama 2 x 24 jam dengan pengamatan tiap 24 jam sekali. Metode yang digunakan untuk perhitungan bakteri coliform adalah metode MPN seri 3 tabung. MPN bakteri coliform dihitung berdasarkan jumlah tabung yang positif pada uji konfirmasi. Perhitungan MPN didasarkan atas jumlah tabung yang bereaksi positif dan negatif dari 3 pengenceran yang berurutan (Anonim, 2008).

$M P N / 100 m L=$ nilai $M P N \times 1 /$

faktor pengencer tengah

Hasil dari analisis data akan dibahas menggunakan metode deskriptif kualitatif dan disajikan pada tabel dan grafik untuk masingmasing dosis kaporit terhadap bakteri Coliform. Penentuan dosis optimum kaporit dari variasi dosis kaporit dan waktu kontak 30 dan 40 menit pada penelitian ini ditampilkan pada kurva breakpoint chlorination.

\section{HASIL DAN PEMBAHASAN}

\section{Kadar Bahan Organik Sebelum Pengolahan}

Kadar bahan organik sebelum pengolahan dijadikan dasar dalam penentuan kaporit yang akan diaplikasikan pada proses klorinasi. Menurut Shovitri (2011), semakin rendah kandungan bahan organik, maka semakin sedikit pula aplikasi pembubuhan klor aktif. Demikian pula sebaliknya, semakin tinggi kandungan bahan organik, maka semakin tinggi pula klor aktif yang dibubuhkan. Menurut Said (2007), bahan organik dapat menambah kebutuhan klor karena keberadaannya menyebabkan penurunan efisiensi proses desinfeksi. Pada hasil penelitian diperoleh rerata kadar bahan organik pada limbah cair Rumah Sakit $\mathrm{X}$ sebelum diolah memakai proses klorinasi adalah $137,26 \mathrm{ppm}$.

\section{Penentuan Dosis dan Waktu Optimum}

Penentuan dosis optimum kaporit yang dibubuhkan dalam sampel air limbah berdasarkan kurva breakpoint chlorination. Breakpoint chlorination (titik retak klorinasi) adalah jumlah klor yang dibutuhkan sehingga semua zat yang dapat teroksidasi dapat dioksidasi, amoniak hilang sebagai gas $\mathrm{N}_{2}$, masih ada residu klor aktif terlarut yang konsentrasinya dianggap perlu untuk pembasmian kuman-kuman menurut Andhika dkk. 
(2013). Penurunan jumlah klor bebas dan masih ada residu klor aktif yang konsentrasinya dianggap perlu sebagai desinfektan. Keuntungan dicapainya breakpoint yaitu senyawa ammonium teroksidisir sempurna (Joko, 2010), mematikan bakteri patogen secara sempurna dan mencegah pertumbuhan lumut.

\section{Residu Klor Setelah Waktu Kontak 30 menit}

Menurut Rosyidi (2010), residu klor aktif yang terdeteksi melalui titrasi iodometri adalah klor bebas $\left(\mathrm{HOCl}\right.$ dan ion $\left.\mathrm{OCl}^{-}\right)$dan klor terikat. Perbandingan $\mathrm{HOCl}$ dan $\mathrm{OCl}^{-}$tergantung pada $\mathrm{pH}$ air. Klor sebagai $\mathrm{HOCL}$ dan $\mathrm{OCl}^{-}$disebut sebagai klorin bebas yang tersedia (free available chlorine) (Said, 2007). Waktu kontak diperkirakan merupakan faktor yang paling penting dalam proses desinfeksi. Semakin lama waktu kontak antara desinfektan dengan mikroba di dalam air, maka daya bunuhnya akan semakin besar (Budiyono dan Sumardiono, 2013). Pada penelitian ini, dilakukan 3 kali pengulangan untuk memperoleh titik Breakpoint dari hubungan residu klor aktif dengan kaporit.

Pada Gambar 1, terbentuknya titik breakpoint chlorination terbagi menjadi 3 zona, yaitu zona 2, zona 3, dan zona 4. Pada zona I, merupakan zona dimana terjadi proses oksidasi senyawa-senyawa yang mudah teroksidasi seperti besi dan mangan (Budiyono dan Sumardiono, 2013). Pada penelitian ini zona 1 tidak terdeteksi karena nilai $\mathrm{pH}$ tidak mencapai lebih dari 8 , nilai $\mathrm{pH}$ awal air limbah sebelum diklorinasi adalah 7,2. Pada zona 2 merupakan zona klorin bereaksi dengan amoniak membentuk kloramin. Zona ini ditandai dengan $\mathrm{pH}$ sebesar 7,1 pada dosis pembubuhan klor ke 130 ppm.

Pada kisaran $\mathrm{pH}>7$ klor aktif cenderung berikatan dengan amoniak membentuk monokloramin $\left(\mathrm{NH}_{2} \mathrm{Cl}\right)$ (Shovitri 2011). Pada zona 3 , merupakan zona pembentukan gas nitrogen,

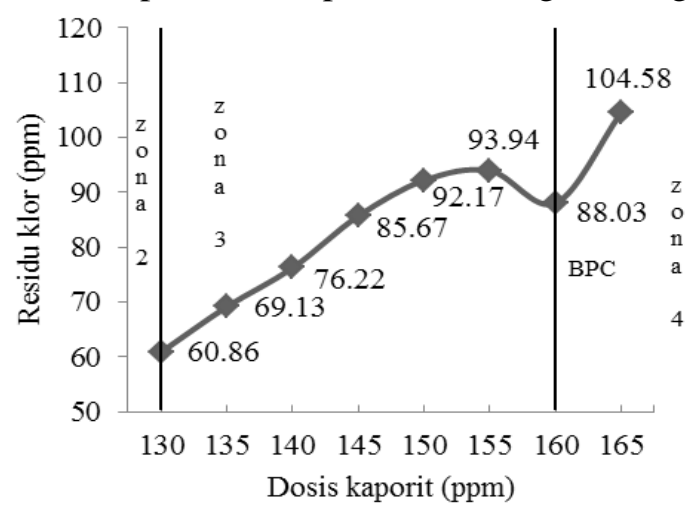

Gambar 1. Hubungan breakpoint chlorination dengan residu klor dan dosis kaporit pada waktu kontak 30 menit. dikloramin, dan $\mathrm{HCl}$ yang menyebabkan terjadinya penurunan $\mathrm{pH}$. Pada zona ini juga kloramin diubah menjadi nitrogen klorida $\left(\mathrm{NCl}_{3}\right), \mathrm{N}_{2} \mathrm{O}$ dan $\mathrm{N}_{2}$. Pada dosis pembubuhan kaporit 135-155 ppm, pH berkisar 6,87 sampai 6,63. Titik puncak kenaikan residu klor terjadi pada dosis kaporit ke 155 ppm dikarenakan setelah dosis tersebut terjadi penurunan residu klor pada dosis 160 ppm yang merupakan titik breakpoint. Data residu klor pada waktu kontak 30 menit merupakan data yang representatif, karena nilai standar deviasi lebih kecil yaitu 14,26 dibandingkan dengan nilai rerata yaitu 83,82 . Nilai standar deviasi yang lebih kecil dari nilai rerata menjelaskan bahwa variasi data pada data residu klor tidak jauh menyimpang, karena standar deviasi merupakan cerminan dari rerata penyimpangan data dari nilai rerata. Selanjutnya, nilai $\mathrm{pH}$ yang merupakan faktor pendukung terbentuknya zona pada kurva breakpoint pada waktu kontak 30 menit disajikan dalam Gambar 2.

Kisaran $\mathrm{pH}$ pada waktu kontak 30 menit masih berada pada kisaran $\mathrm{pH}$ 6-7. Nilai $\mathrm{pH} 7,1$ terdapat pada dosis kaporit 130 ppm yang menandakan bahwa pada dosis tersebut terjadi reaksi yang ada pada zona 1 sesuai dengan kisaran $\mathrm{pH}$ terbentuknya monokloramin. Breakpoint pada penelitian ini terjadi mungkin karena kadar zat organik dan anorganik dalam sampel telah teroksidasi, sedangkan pembubuhan klor aktif terus menerus dibubuhkan yang dilihat dari nilai residu klor yang menurun pada dosis $160 \mathrm{ppm}$. Pada zona 3 merupakan zona setelah terjadinya breakpoint chlorination yang ditandai oleh kenaikan kembali residu klor pada dosis pembubuhan kaporit 165 ppm. Data nilai pH pada waktu kontak 30 menit merupakan data yang representatif, karena nilai standar deviasi lebih kecil yaitu 0,15 dibandingkan nilai rerata yaitu 6,76. Nilai standar deviasi yang lebih kecil dari nilai rerata menjelaskan bahwa variasi data pada data nilai $\mathrm{pH}$ tidak jauh menyimpang.

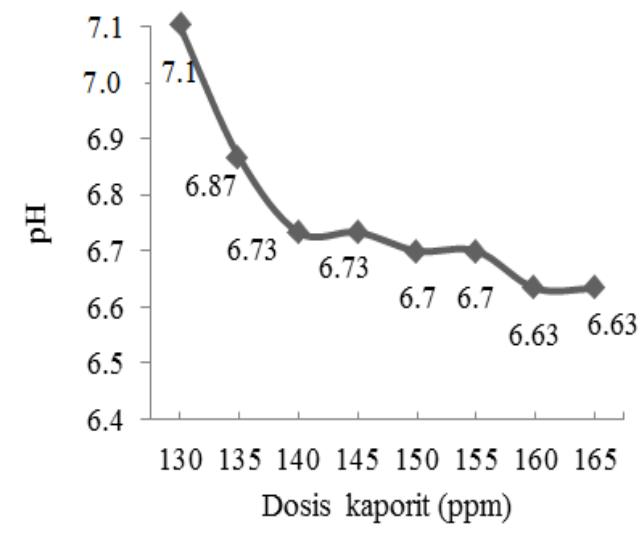

Gambar 2. Pengujian pH waktu kontak 30 menit. 
Menurut Sutrisno (2010) pada proses penjernihan air dan air limbah, $\mathrm{pH}$ menjadi indikator untuk meningkatkan efisiensi proses penjernihan. Dapat dilihat pada Gambar 2 bahwa $\mathrm{pH}$ mengalami penurunan nilai seiring dengan bertambahnya dosis kaporit yang dibubuhkan karena kaporit atau $\mathrm{Ca}(\mathrm{OCl})_{2}$ memiliki sifat yang asam (Joko, 2010). Sifat asam dari kaporit inilah yang mempengaruhi nilai $\mathrm{pH}$ selama proses klorinasi.

\section{Nilai MPN Coliform Setelah Waktu Kontak 30 menit}

Pada penelitian ini, dilakukan pengujian coliform dengan melakukan pengenceran bertingkat, yaitu $10^{-1}, 10^{-2}$, dan $10^{-3}$ dengan 5 seri tabung. Maksud dari dilakukannya pengenceran bertingkat dengan 5 seri tabung ialah sebagai penentuan nilai MPN, karena semakin banyak seri tabung yang digunakan untuk pengujian coliform, maka semakin teliti nilai MPN yang diperoleh per $100 \mathrm{~mL}$ (Boekoesoe, 2010).

Pada waktu kontak 30 menit diambil 3 sampel setelah perlakuan dengan klor aktif, yaitu sebelum breakpoint, breakpoint, dan sesudah breakpoint. Pengambilan ketiga sampel ini bertujuan untuk mengetahui hubungan dari ketiga sampel tersebut dengan waktu kontak 30 menit pada saat klorinasi serta mengetahui pengaruh dari titik breakpoint terhadap penurunan bakteri Coliform.

Pada Gambar 3, diperoleh rerata nilai MPN Coliform dari 3 kali pengulangan pada waktu kontak 30 menit, berturut-turut adalah 2.266 MPN/100mL dengan persentase penurunan 98,58\% pada dosis $155 \mathrm{ppm}, 2.866 \mathrm{MPN} / 100 \mathrm{~mL}$ dengan persentase penurunan $98,21 \%$ pada dosis kaporit $160 \mathrm{ppm}$ dan $1.833 \mathrm{MPN} / 100 \mathrm{~mL}$ dengan persentase penurunan $98,85 \%$ pada dosis $165 \mathrm{ppm}$. Persentase penurunan terbesar terjadi pada dosis 165 ppm di 3

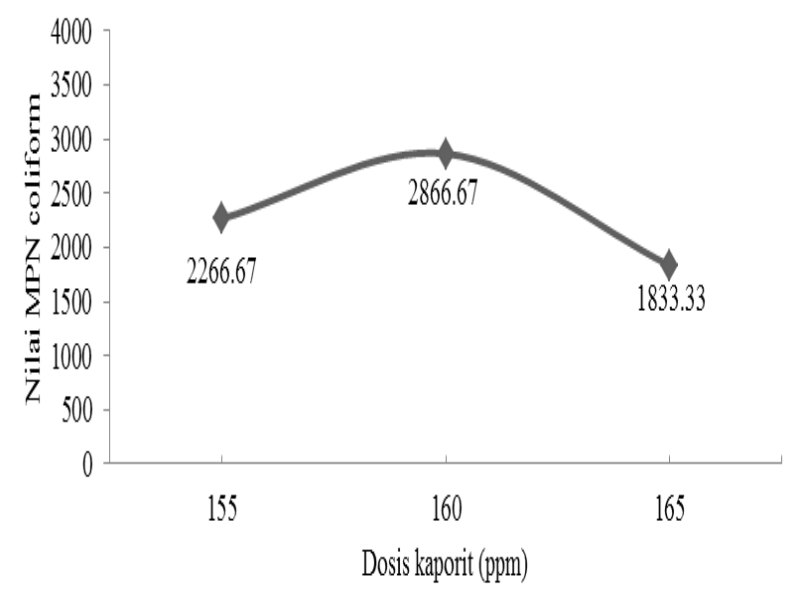

Gambar 3. Nilai MPN coliform waktu kontak 30 menit. kali pengulangan. Data nilai MPN Coliform pada waktu kontak 30 menit merupakan data yang representatif, karena nilai standar deviasi lebih kecil yaitu 518 dibandingkan dengan nilai rerata yaitu 2.322. Nilai standar deviasi yang lebih kecil dari nilai rerata menjelaskan bahwa variasi data pada data nilai MPN Coliform tidak jauh menyimpang, jika nilai standar deviasi yang diperoleh jauh lebih besar dibandingkan nilai rerata, maka data tidak representatif.

\section{Residu Klor Setelah Waktu Kontak 40 menit}

Setelah perlakuan sampel air limbah yang dibubuhi klor aktif selama 30 menit sebagai waktu kontak, maka selanjutnya dilakukan penambahan waktu kontak menjadi 40 menit dan dilakukan pengulangan yang sama yakni sebanyak 3 kali. Menurut Budiyono dan Sumardiono (2013) kisaran waktu untuk proses klorinasi minimal adalah 30 menit sampai 60 menit. Residu klor setelah dikontakkan selama 40 menit dengan kaporit disajikan dalam Gambar 4

Pada Gambar 4, terbentuknya titik breakpoint chlorination terbagi menjadi 3 zona, yaitu zona 2, zona 3 , dan zona 4 . Pada zona 1 , ditandai dengan nilai $\mathrm{pH}>8$ dan nilai $\mathrm{pH}>8$ yang tidak terdeteksi pada penelitian ini karena $\mathrm{pH}$ awal limbah cair sebelum dikontakkan dengan kaporit adalah 7,2. Pada zona 1 terjadi proses oksidasi senyawa yang mudah teroksidasi seperti besi dan mangan $\left(\mathrm{Fe}^{2+}\right.$ dan $\mathrm{Mn}^{2+}$ ) (Budiyono dan Sumardiono, 2013). Pada zona 2 merupakan zona klorin yang bereaksi dengan amoniak membentuk kloramin. Zona ini ditandai dengan $\mathrm{pH}$ yaitu 7,1 pada dosis pembubuhan kaporit ke 130 ppm.

Pada zona 3, merupakan zona pembentukan gas nitrogen, dikloramin, dan $\mathrm{HCl}$ yang menyebabkan terjadinya penurunan $\mathrm{pH}$. Pada dosis kaporit 135-155 ppm maka pH berkisar 6,87-6,63

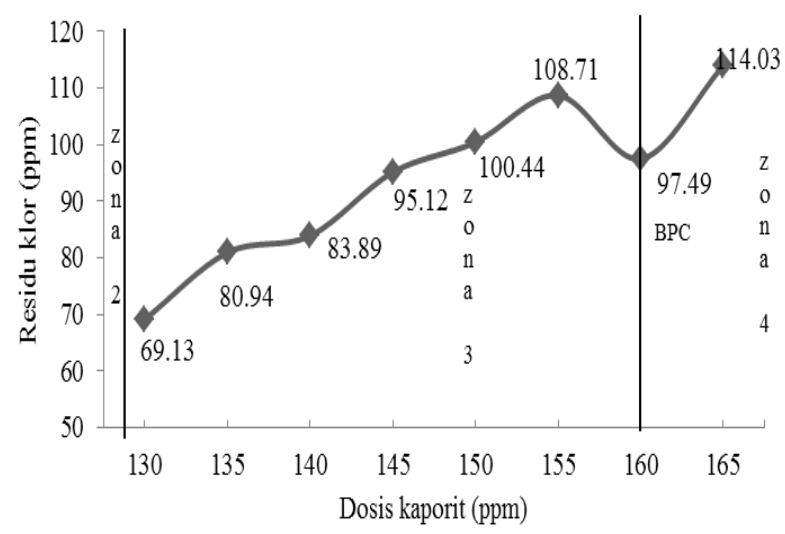

Gambar 4. Hubungan breakpoint chlorination dengan residu klor dan dosis kaporit pada waktu kontak 40 menit. 
dengan titik puncak kenaikan residu klor yang terjadi pada dosis kaporit $155 \mathrm{ppm}$.

Pada kelima dosis pembubuhan kaporit tersebut residu klor semakin naik karena semakin tinggi dosis pembubuhan yang diberikan pada perlakuan dengan sampel air limbah. Setelah dosis pembubuhan mencapai titik puncak, terjadi penurunan residu klor pada dosis 160 ppm yang merupakan titik breakpoint. Data residu klor pada waktu kontak 40 menit merupakan data yang representatif, karena nilai standar deviasi lebih kecil yaitu 14,94 dibandingkan nilai rerata yaitu 93,72. Nilai standar deviasi yang lebih kecil dari nilai rerata menjelaskan bahwa variasi data pada data residu klor tidak jauh menyimpang, karena standar deviasi merupakan cerminan dari rerata penyimpangan data dari nilai rerata. Nilai $\mathrm{pH}$ pada waktu kontak 40 menit disajikan pada Gambar 5.

Pada penelitian ini residu klor aktif yang diperoleh adalah klor bebas $\left(\mathrm{HOCl}\right.$ dan ion $\left.\mathrm{OCl}^{-}\right)$ dan klor terikat (kloramin). Klorin sebagai desinfektan terutama bekerja dalam bentuk asam hipoklorit $(\mathrm{HOCl})$ dan sebagian kecil dalam bentuk ion hipoklorit $\left(\mathrm{OCl}^{-}\right)$. Klorin dapat bekerja secara efektif sebagai desinfektan jika berada dalam air dengan $\mathrm{pH}$ 7. Jika nilai $\mathrm{pH}$ air lebih dari 8,5, maka 90\% dari asam hipoklorit itu akan mengalami ionisasi menjadi ion hipoklorit. Dengan demikian khasiat desinfektan yang dimiliki klorin akan menjadi lemah atau berkurang (Andhika dkk, 2013). Data nilai pH pada waktu kontak 40 menit merupakan data yang representatif, karena nilai standar deviasi lebih kecil yaitu 0,14 dibandingkan dengan nilai rerata yaitu 6,82. Nilai standar deviasi yang lebih kecil dari nilai rerata menjelaskan bahwa variasi data pada data nilai $\mathrm{pH}$ tidak jauh menyimpang, karena standar deviasi yang lebih besar dari nilai rerata menunjukkan bahwa data tidak representatif.

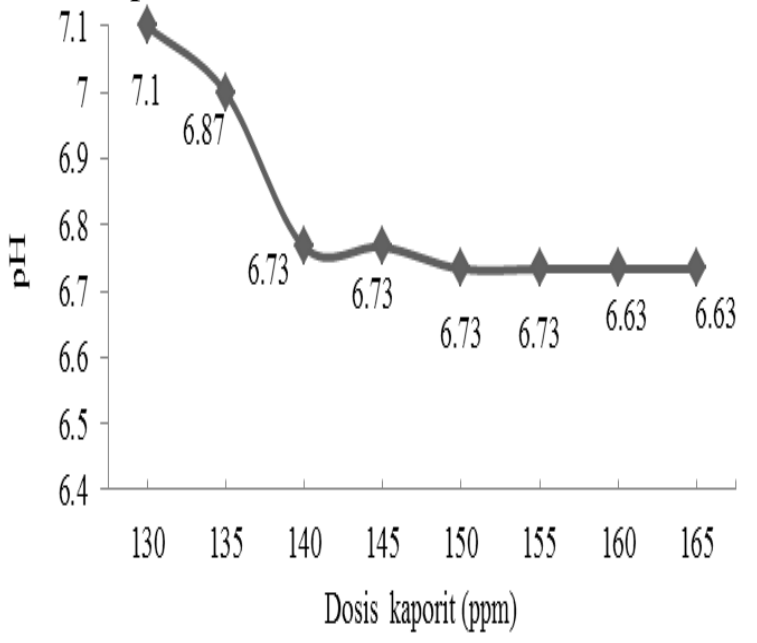

Gambar 5. Pengujian pH waktu kontak 40 menit.

\section{Nilai MPN Coliform Setelah Waktu Kontak 40 menit}

Untuk mengetahui jumlah Coliform dalam pemeriksaan kualitas air dapat digunakan metode MPN dalam metode MPN digunakan medium cair didalam tabung reaksi, dimana perhitungan dilakukan berdasarkan jumlah tabung yang positif yang ditumbuhi oleh jasad renik setelah diinkubasi pada suhu tertentu. Pengaman tabung positif terbaik yaitu untuk jasad renik pembentuk gas. Untuk setiap pencernaan pada umumnya digunakan tiga atau lima seri tabung. Lebih banyak tabung yang digunakan menunjukkan ketelitian yang lebih tinggi (Boekoesoe, 2010)

Berdasarkan Gambar 6, diperoleh rerata nilai MPN Coliform dari 3 kali pengulangan pada waktu kontak 40 menit, berturut-turut adalah 3.033 MPN/100 mL dengan persentase penurunan 98,10 $\%$ pada dosis pembubuhan $155 \mathrm{ppm}$ diperoleh nilai Coliform sebesar $1.866 \mathrm{MPN} / 100 \mathrm{~mL}$ dengan persentase penurunan $98,83 \%$ pada dosis pembubuhan $160 \mathrm{ppm}$ dan $1.066 \mathrm{MPN} / 100 \mathrm{~mL}$ dengan persentase penurunan $99,33 \%$ pada dosis pembubuhan $165 \mathrm{ppm}$. Persentase penurunan terbesar terjadi pada dosis 165 ppm di 3 kali pengulangan. Dari ketiga dosis tersebut, diketahui bahwa pada dosis setelah breakpoint yaitu 165 ppm terjadi penurunan nilai MPN Coliform yang signifikan yaitu 99,33\%. Data nilai MPN Coliform pada waktu kontak 40 menit merupakan data yang representatif, karena nilai standar deviasi lebih kecil yaitu 989 dibandingkan nilai rerata yaitu 1.988 . Data nilai MPN Coliform tidak jauh menyimpang karena nilai standar deviasi yang lebih kecil dari nilai rerata, standar deviasi merupakan gambaran data yang representatif jika standar deviasi lebih kecil dibanding nilai rerata.

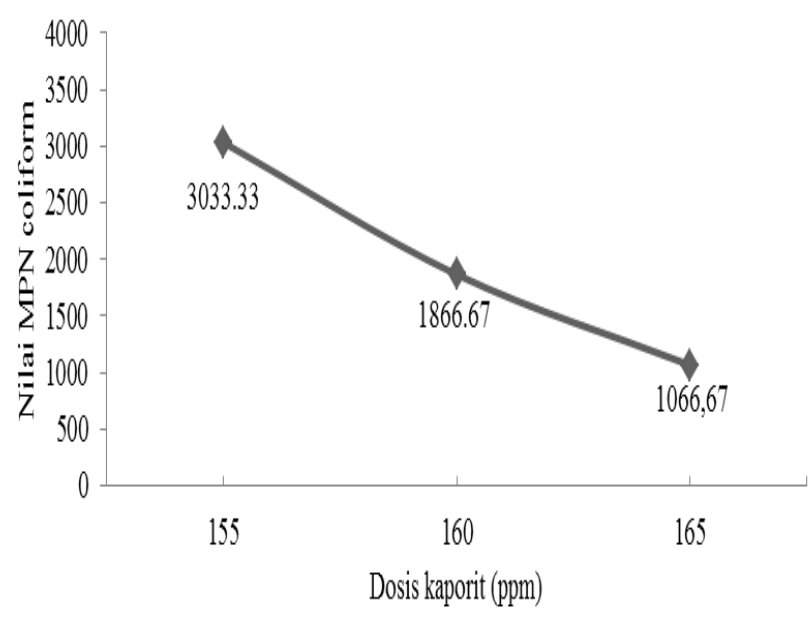

Gambar 6. Nilai MPN coliform waktu kontak 40 menit. 
Menurut Said (2007), klorin menyebabkan kerusakan pada sel bakteri. Jenis perusakan tersebut adalah :

a. Perusakan kemampuan permeabilitas sel (disruption of cell permeability).

Klor bebas merusak membran dari sel bakteri, hal ini menyebabkan sel kehilangan permeabilitasnya (kemampuan menembus) dan merusak fungsi sel lainnya. Pemaparan pada klor menyebabkan kebocoran protein, RNA dan DNA. Perusakan kemampuan permeabilitas merupakan penyebab perusakan spora bakteri oleh klor.

b. Perusakan asam nukleat dan enzim (Damage to nucleic acids and enzymes).

Klorin merusak juga asam nukleat bakteri, demikian pula enzim. Salah satu akibat pengurangan aktivitas katalis adalah penghambatan oleh akumulasi hidrogen peroxida. Cara kerja klor terhadap virus tergantung pada jenis virus.

Melalui residu klor diperoleh titik breakpoint yaitu dosis 160 ppm pada waktu kontak 30 dan 40 menit. Dosis 160 ppm merupakan dosis optimum dengan rerata residu klor pada waktu 30 menit adalah 88,03 ppm dan pada waktu kontak 40 menit adalah 97,5 ppm. Dosis optimum pada penelitian ini berdasarkan pada kurva breakpoint chlorination yang bertujuan untuk mengontrol residu klor yang akan dibuang ke lingkungan perairan. Efektivitas penggunaan kaporit $60 \%$ di titik breakpoint yaitu dosis 160 ppm pada waktu kontak 30 dan 40 menit telah mampu menurunkan nilai Coliform hingga $98,83 \%$.

\section{KESIMPULAN}

Penentuan dosis optimum kaporit sebagai desinfektan untuk menurunkan bakteri coliform menggunakan kurva breakpoint chlorination untuk memperoleh residu klor dari titik breakpoint, merupakan cara penggunaan kaporit yang efektif sebagai desinfektan.

\section{DAFTAR PUSTAKA}

Arifiani, 2007. Evaluasi Desain Instalasi Pengolahan Air PDAM Ibukota Kecamatan Prambanan Kabupaten Klaten. Jurnal Presipitasi, 3(2):78-85.
Ali, M., 2010. Peran Proses Desinfeksi dalam Upaya Peningkatan Kualitas Produk Air Bersih. Universitas Pembangunan Veteran Nasional, Surabaya.

Andhika J.D., Duta, Trijoko, Hanani, dan Yusniar. 2013. Kadar Sisa Chlor dan Kandungan Bakteri E. Coli Perusahaan Air Minum Tirta Moedal Semarang Sebelum dan Sesudah Pengolahan. Jurnal Kesehatan Masyarakat 2(2):1-9.

Anonim, 1999. Pengelolaan Aman Limbah Layanan Kesehatan. Penerbit Buku Kedokteran, Jakarta.

Anonim, 2004. Air dan Air Limbah-Bagian 22: Cara Uji Nilai Permanganat secara Titrimetri. SNI 06-6989.22-200, Jakarta.

Anonim, 2008. Metode Pengujian Cemaran Mikroba dalam Daging, Telur dan Susu, serta Hasil Olahannya. SNI 2897:2008. Jakarta.

Asmadi, 2013. Pengelolaan Limbah Medis Rumah Sakit. Gosyen Publishing, Yogyakarta, pp 3-1

Budiyono dan Sumardiono, S., 2013. Teknik Pengolahan Air. Graha Ilmu, Yogyakarta, pp 103-110.

Boekoesoe, L., 2010. Tingkat Kualitas Bakteriologis Air Bersih di Desa Sosial Kecamatan Paguyaman Kabupaten Boalemo. Inovasi 7(4):246-249.

Davis, M.L., 2011. Water and Wastewater Engineering. McGraw-Hill, New York.

Joko. T. 2010. Unit Produksi Sistem Penyediaan Air Minum. Graha Ilmu, Yogyakarta.

Rosyidi, M.B., 2010. Pengaruh Breakpoint Chlorination (BPC) terhadap Jumlah Bakteri Koliform dari Limbah Cair Rumah Sakit Umum Sidoarjo. Institut Teknologi Surabaya, Surabaya.

Said, N.I., 2007. Desinfeksi untuk Proses Pengolahan Air Minum. Jurnal Air Indonesia, 3(1):15-20.

Sutrisno, T., 2010. Teknologi Penyediaan Air Bersih. Rineka Cipta, Jakarta. pp:34-35.

Shovitri, M., Rosyidi, M.B., Nurhatika, S., dan Zulaika, E., 2011. Apakah Breakpoint chlorination (BPC) selalu Aplikatif untuk Mengolah Limbah Cair Rumah Sakit?. Jurnal Purifikasi, 12:83-92. 